\title{
Removal of iron and arsenic (III) from drinking water using iron oxide-coated sand and limestone
}

\author{
Rashmi R. Devi • Iohborlang M. Umlong • Bodhaditya Das • \\ Kusum Borah • Ashim J. Thakur • Prasanta K. Raul • \\ Saumen Banerjee · Lokendra Singh
}

Received: 6 December 2012/Accepted: 25 October 2013/Published online: 9 November 2013

(C) The Author(s) 2013. This article is published with open access at Springerlink.com

\begin{abstract}
A method for removal of iron and arsenic (III) from contaminated water using iron oxide-coated sand and limestone has been developed for drinking water. For the intended use, sand was coated with ferric chloride and used as filtering media. Limestone was added onto the coated sand and the effect of limestone addition on removal efficiency of iron and arsenic was monitored. Both batch and column experiments were conducted to investigate the efficiency of coated sand and limestone as filtering media. Maximum removal of iron $(99.8 \%$ ) was obtained with coated sand at a dose of $5 \mathrm{~g} / 100 \mathrm{ml}$ and by adding $0.2 \mathrm{~g} /$ $100 \mathrm{ml}$ of limestone at $\mathrm{pH}$ 7.3. Arsenic (III) removal efficiency increased with the increased dose of coated sand and was best removed at $\mathrm{pH}$ 7.12. The maximum adsorption capacity for arsenic (III) obtained from Langmuir model was found to be $0.075 \mathrm{mg} / \mathrm{g}$ and the kinetics data followed pseudo-first order better than pseudo-second order. Energy dispersive X-ray analysis and FT-IR study proved the removal of iron and arsenic. Column experiment showed removal of iron and arsenic (III) to $<0.3 \mathrm{mg} / \mathrm{l}$ and $10 \mu \mathrm{g} / \mathrm{l}$, respectively, from an initial concentration of $20 \mathrm{mg} / \mathrm{l}$ (iron) and $200 \mu \mathrm{g} / \mathrm{l}$ (arsenic).
\end{abstract}

Keywords Water - Iron - Arsenic - Coated sand · Limestone

R. R. Devi ( $₫)$ - I. M. Umlong · B. Das · K. Borah ·

P. K. Raul · S. Banerjee - L. Singh

Defence Research Laboratory, Post Bag No. 2,

Tezpur 784 001, Assam, India

e-mail: devi_rashmi@yahoo.com

A. J. Thakur

Department of Chemical Sciences, Tezpur University,

PO: Napaam, Tezpur 784 028, Assam, India

\section{Introduction}

Water is not only regarded as the matrix of life, but it is also essential for the sustainable economical growth of a nation. India is one of the countries bestowed with highpotential and nature-gifted rich water resources. Despite this, there is a scarcity of potable quality water. Population explosion, economic progress, poor management and contamination of water sources are the main reasons for scarcity of assured quality of water (Garg and Hassan 2007). High iron content in drinking water is a major problem in most parts of the northeastern (NE) region of India (Singh and Khanikar 2009; Singh et al. 2008). In India, NE states along with Jharkhand, Bihar, West Bengal, Madhya Pradesh, Uttar Pradesh, etc. are badly affected by groundwater contaminated with arsenic (Chakraborti et al. 2004; Chakrabarti et al. 2008). South Tripura was also found to have high contamination of water with respect to iron and arsenic (Banerjee et al. 2011). Treatment requirements for the removal of dissolved iron and arsenic from water are well understood. Considering the lethal impact of arsenic, WHO has recommended maximum contaminant level of arsenic as $10 \mu \mathrm{g} / \mathrm{l}$ in drinking water (Gupta et al. 2005). The two oxidation states of As (III) and As (V) are common in natural environments. The toxicity of a given arsenical is related to the rate of its clearance from the body and therefore to its degree of accumulation in tissue. In general, toxicity increases in the sequence: organic arsenical $<\mathrm{As}(\mathrm{V})<\mathrm{As}$ (III) $<$ arsine $\left(\mathrm{AsH}_{3}\right)$ (Klaassen 2001). Numerous methods are available for removal of arsenic from water including iron-modified activated carbon, chitosan-coated biosorbent, oxides, clay minerals, etc. (Chen et al. 2007; Boddu et al. 2008; Goldberg 2002). Various adsorption materials have been used for this purpose such as activated alumina, activated 
carbon, fly ash, ferric hydroxide and zero valent iron (Jeon et al. 2009; Twindell et al. 2005; Ladeira et al. 2001; Wang et al. 2000). However, some of these processes are expensive or require the control of $\mathrm{pH}$ and/or other parameters to achieve the optimum arsenic removal capacity; therefore, a more effective and economical technique would be highly desirable. Time and temperature had significant effects on the removal efficiencies. Adsorption of arsenic on iron oxide-coated sand method is one of the emerging technologies for arsenic removal (Gupta et al. 2005; Joshi and Chaudhuri 1996). Iron and arsenic removal are both $\mathrm{pH}$ dependent. Twindell et al. reported the precipitation of $\mathrm{Fe}(\mathrm{III})$-arsenate or arsenate coprecipitation with excess iron. It is found that removal of iron also simultaneously helps in arsenic removal from drinking water.

Limestone is one of the easily available and cheap materials that helps in the removal of iron and also acts as a pH controller (Sim et al. 2001; Mackintosh and Villiers 1998). Calcium carbonate, which is a main component of limestone, provides an alternative means of neutralizing acid water and the production of smaller sludge ( $\mathrm{Vu}$ et al. 2003). Limestone is not only an affordable substrate, but also contributes significant secondary beneficial characteristics such as a heterogeneous surface, secondary binding site, buffering quality and repurposing capability (Benadin 2011).

In a study by Ghaly et al. (2007), limestone and sandstone/limestone filters were found to be effective in removing dissolved iron and manganese from landfill leachate under field conditions.

Although reports are available regarding removal of arsenic using coated sand, to the best of our knowledge, removal of iron along with arsenic using iron oxide-coated sand is not reported. Report on removal of arsenic and iron using coated sand and the effect of limestone on the removal efficiency is also not found.

This paper explores the possibilities of using iron oxidecoated sand in combination with limestone as filtering media for both iron and arsenic (III) removal. The effects of adsorbent dose, initial arsenic and iron concentration on the removal of arsenic species along with $\mathrm{Fe}$ have been reported.

\section{Experimental}

\section{Materials}

Stock solutions of $1,000 \mathrm{mg} / \mathrm{l}$ arsenic (III) and iron were prepared from $\mathrm{As}_{2} \mathrm{O}_{3}$ and $\mathrm{FeSO}_{4} \bullet 7 \mathrm{H}_{2} \mathrm{O}$, respectively, using double-distilled water. All reagents used were of analytical grade and obtained from Merck, India. Limestone was obtained from Mawlong mining site, Meghalaya, India. EDX analysis of limestone showed the presence of $\mathrm{CaCO}_{3}$ and traces of silica. The weight percentages of elements are shown in Table 1.

Preparation of iron oxide-coated sand

Iron oxide-coated sand was prepared using a procedure described elsewhere (Gupta et al. 2005; Joshi and Chaudhuri 1996). Washed and dried river sand (200 g) of particle size $0.1-0.8 \mathrm{~mm}$ was mixed with $80 \mathrm{ml}$ of a $2 \mathrm{M}$ ferric chloride solution at $\mathrm{pH} 10.5$ for $2 \mathrm{~min}$. The mixture was then dried in an oven at $110^{\circ} \mathrm{C}$ for $20 \mathrm{~h}$. The coated sand was washed thoroughly with distilled water until clear water was visible. Finally, the mixture was dried at $105{ }^{\circ} \mathrm{C}$.

\section{Batch experiments}

Batch experiments were designed to investigate the efficiency of iron and arsenic (III) removal with different dosages of coated sand and limestone and the effect of initial concentrations of iron and arsenic, respectively, at fixed dosage of coated sand and limestone. Erlenmeyer flasks $(250 \mathrm{ml})$ containing a fixed dosage of coated sand and limestone with $100 \mathrm{ml}$ each of iron or arsenic (III) solution were placed on a mechanical shaker at room temperature $\left(27^{\circ} \mathrm{C} \pm 1\right)$ for a fixed time period $(2 \mathrm{~h})$. The flask was then removed and the solution was filtered through Whatman No. 41 filter paper. Each batch was repeated three times and the mean value was taken for computation. The effect of limestone addition on the removal efficiency of iron and arsenic (III) was observed by varying the dose of limestone in each batch of coated sand. The same dose of limestone was added to different doses of coated sand in every batch. The effect was also observed without using limestone with different doses of coated sand. The optimized dose of limestone and coated sand was evaluated and used to observe the removal efficiency with varying concentrations of iron and arsenic (III)-spiked water.

\section{Column experiment}

Column experiment was conducted using a fabricated column of $120 \mathrm{~cm}$ height and $7.0 \mathrm{~cm}$ diameter having a

Table 1 Weight percent of elements present in limestone

\begin{tabular}{lcc}
\hline Element & Weight $\%$ & Atomic $\%$ \\
\hline $\mathrm{C}$ & 6.10 & 10.24 \\
$\mathrm{O}$ & 55.91 & 70.25 \\
$\mathrm{Si}$ & 0.32 & 0.23 \\
$\mathrm{Ca}$ & 37.67 & 18.98 \\
\hline
\end{tabular}


water outlet (Fig. 1). The column was packed with uncoated sand which acts as a filter media to trap the precipitated particles, coated sand and limestone with specific particle size and bed volume (Table 2). Spiked water containing iron $(20 \mathrm{mg} / \mathrm{l})$ and arsenic $(200 \mu \mathrm{g} / \mathrm{l})$ was allowed to pass through the column at four different flow rates of $1,2,4$ and $7 \mathrm{l} / \mathrm{h}$, respectively. A total of 401 iron and arsenic (III)-spiked water was allowed to pass through the column in one cycle of run, and the filtered water collected after a particular time interval was analysed for residual iron and arsenic content. A total of ten cycles of run were passed through the column.

Iron and arsenic (III) measurement

Iron concentrations in the samples were measured by potassium thiocyanate method using a UV-visible spectrophotometer (Specord 40, Analytic Jena) at $\lambda_{\max } 480 \mathrm{~nm}$.

Atomic absorption spectrometer (AAnalyst 200, Perkin Elmer) equipped with an electrode discharge lamp was employed to measure the arsenic concentration. An automatic intermittent hydride generation device was used to convert arsenic in water samples to arsenic hydride. The hydrides were then purged continuously by argon gas into the atomizer for concentration measurements.

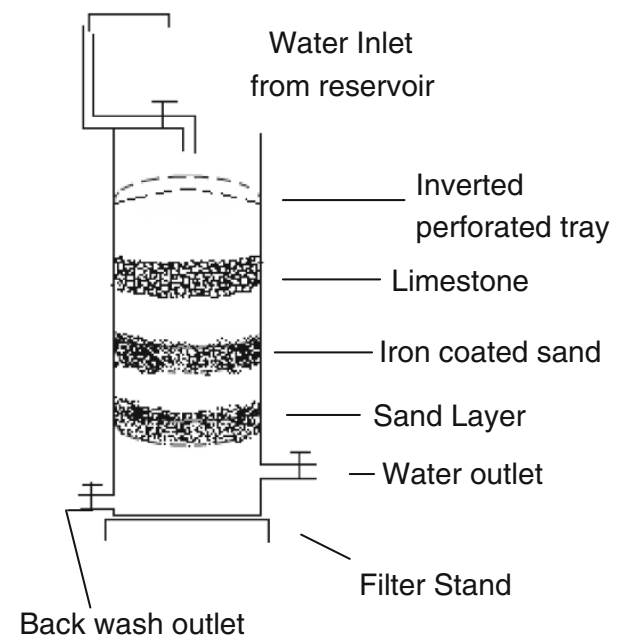

Fig. 1 Schematic diagram of a fabricated column for iron and arsenic removal

Table 2 Particle size and bed volume of the filter medium used in the column

\begin{tabular}{lcl}
\hline Filter medium used & Particle size $(\mathrm{mm})$ & Bed volume $\left(\mathrm{cm}^{3}\right)$ \\
\hline Limestone $(69 \mathrm{~g})$ & $15-20$ & 69 \\
Iron-coated sand $(72 \mathrm{~g})$ & $0.8-1$ & 70 \\
Sand $(100 \mathrm{~g})$ & $0.1-0.8$ & 92 \\
\hline
\end{tabular}

EDX analysis and FT-IR study

EDX analysis was carried out using an EDX analyser attached to an SEM instrument (Model Jeol 6390LV). FTIR spectra of the samples were taken with the help of an FT-IR spectrophotometer using the $\mathrm{KBr}$ pellet method (Nicolet impact 410).

\section{Results and discussions}

Batch studies

Removal efficiency of iron using coated sand and limestone

Figure 2a represents the batch study results on the removal of iron using coated sand and varying limestone in each batch. The dose of coated sand was varied from 1 to $20 \mathrm{~g} /$ $100 \mathrm{ml}$ in each batch. The limestone concentration was varied from 0.1 to $1 \mathrm{~g} / 100 \mathrm{ml}$. Again, iron removal efficiency was observed to increase with increasing dose of coated sand in each batch. Removal efficiency of iron was higher when limestone was added to coated sand. It was observed that $99.8 \%$ iron was removed when $0.2 \mathrm{~g} / 100 \mathrm{ml}$ of limestone was added to coated sand $(5 \mathrm{~g} / 100 \mathrm{ml})$ at $\mathrm{pH}$ 7.3. Literature says that oxidation of Fe(II) is catalysed by the reaction product $\mathrm{Fe}(\mathrm{III})$ (Mackintosh and Villiers 1998). Iron oxide-coated sand was able to remove iron
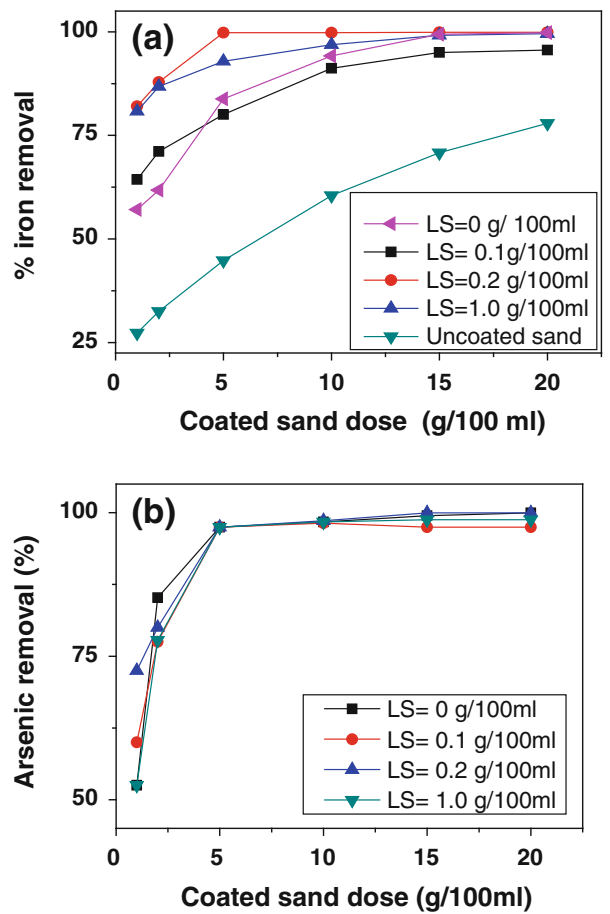

Fig. 2 Removal efficiency of iron (a) and arsenic (b) using coated sand at different limestone concentrations ( $L S$ limestone)

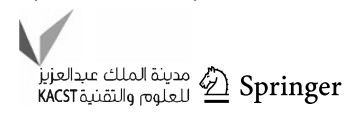


from contaminated water compared to uncoated sand, as the oxidation of soluble iron $\left(\mathrm{Fe}^{2+}\right)$ to insoluble $\left(\mathrm{Fe}^{3+}\right)$ takes place at the surface of iron oxide-coated sand and gets precipitated. Iron removal efficiency was higher when limestone was added to coated sand. Calcium carbonate, which is a main component of limestone, provides an alternative means of neutralizing acid water and maintaining $\mathrm{pH}$ level over 7.0 that enhances the efficiency of the oxidation of ferrous iron (Benadin 2011).

It was observed that uncoated sand cannot remove arsenic from solution. Figure $2 \mathrm{~b}$ shows that arsenic (III) removal efficiency increased with increasing dose of coated sand. 97.5\% arsenic was removed at coated sand dose concentration of $5 \mathrm{~g} / 100 \mathrm{ml}$. Varied concentrations of limestone $(0.1-1 \mathrm{~g} / 100 \mathrm{ml})$ were added to coated sand and the effect on arsenic removal was observed. The removal efficiency $(97.5 \%)$ on the removal of arsenic (III) was obtained whether limestone was added or not to $5 \mathrm{~g} / 100 \mathrm{ml}$ coated sand (Fig. 1b), thus indicating that limestone is not directly involved in the removal of arsenic. Further, it was observed that arsenic was best removed at $\mathrm{pH} 7.12$ under the experimental condition. Similar results were also obtained by Gupta et al. (2005). The adsorption of arsenate and arsenite increases as $\mathrm{pH}$ becomes more alkaline, because the positive charges on the iron cations attract the negative charges of the arsenic anions, creating ionic bonds (Benadin 2011).

Effect of initial concentration of iron and arsenic on removal efficiency of iron and arsenic (III)

To investigate the effect of variation of initial concentration of iron, the iron concentration was varied from 5 to $30 \mathrm{mg} / \mathrm{l}$ using the dose of coated sand as $5 \mathrm{~g} / 100 \mathrm{ml}$ and adding $0.2 \mathrm{~g} / 100 \mathrm{ml}$ limestone (Fig. 3). $99 \%$ iron was

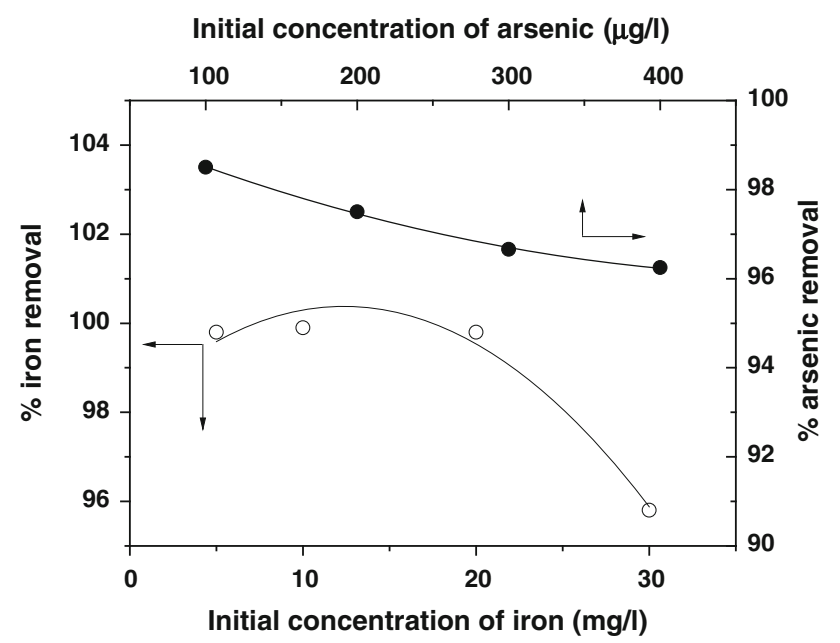

Fig. 3 Iron and arsenic removal with increasing initial concentration removed for initial iron concentration up to $20 \mathrm{mg} / \mathrm{l}$ within $\mathrm{pH}$ 7.2-7.6. On the other hand, iron removal efficiency decreased to $95 \%$ at $\mathrm{pH} 7.14$ when the initial iron concentration was $30 \mathrm{mg} / \mathrm{l}$. The analysis was carried out to assess the effect of initial arsenic (III) concentration on the removal efficiency; arsenic concentration was varied from 100 to $400 \mu \mathrm{g} / \mathrm{l}$ using $5 \mathrm{~g} / 100 \mathrm{ml}$ dosage of coated sand. It was seen from Fig. 2 that when initial arsenic (III) concentration was varied from 100 to $400 \mu \mathrm{g} / \mathrm{l}$, arsenic removal efficiency slowly decreased from 98.6 to $96 \%$.

\section{Effect of $\mathrm{pH}$}

The effect of $\mathrm{pH}$ on the arsenic (III) adsorption on to iron oxide-coated sand (Fig. 4) was studied at four different $\mathrm{pH}$ viz. $\mathrm{pH} 4.8,7.1,8.5$ and $\mathrm{pH} 10.4$, respectively. It was observed that removal of arsenic (III) was best achieved at $\mathrm{pH}$ above neutral. The adsorption of arsenic (III) increases as $\mathrm{pH}$ becomes more alkaline, because the positive charges on the iron cations attract the negative charges of the arsenic anions, creating ionic bonds (Benadin 2011).

\section{Adsorption kinetics}

Adsorption kinetics models are used to investigate the mechanism of adsorption. Two models are adopted and they are pseudo-first order model given as:

$q_{\mathrm{t}}=q_{\mathrm{e}}\left(1-\exp \left(-k_{1} t\right)\right.$

and pseudo-second order model represented by the following equations:

$q_{\mathrm{t}}=\frac{q_{\mathrm{e}}^{2} k_{2} t}{1+q_{\mathrm{e}} k_{2} t}$

where $q_{\mathrm{e}}$ and $q_{\mathrm{t}}$ are the amount of adsorbate at equilibrium and time $t$ (both in $\mathrm{mg} / \mathrm{g}$ ); $k_{1}$ is the first-order rate constant

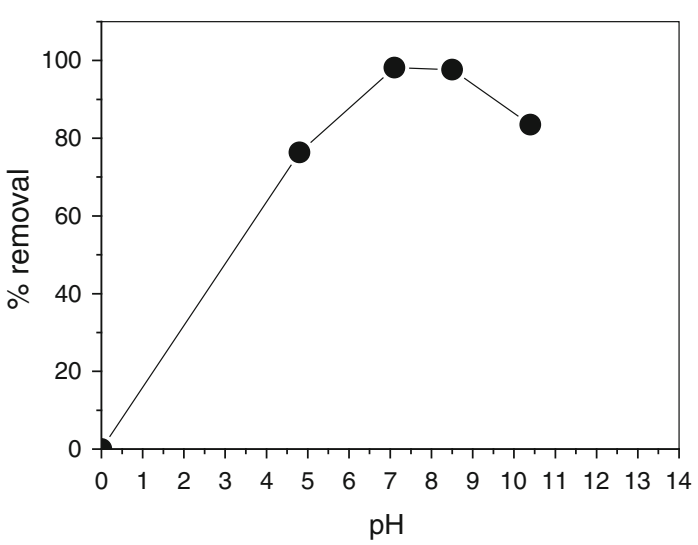

Fig. 4 Effect of solution $\mathrm{pH}$ on the removal efficiency of iron oxidecoated sand 
Fig. 5 (a) pseudo-first order kinetic plots; (b) pseudo-second order plot for the sorption of arsenic (III) onto adsorbent
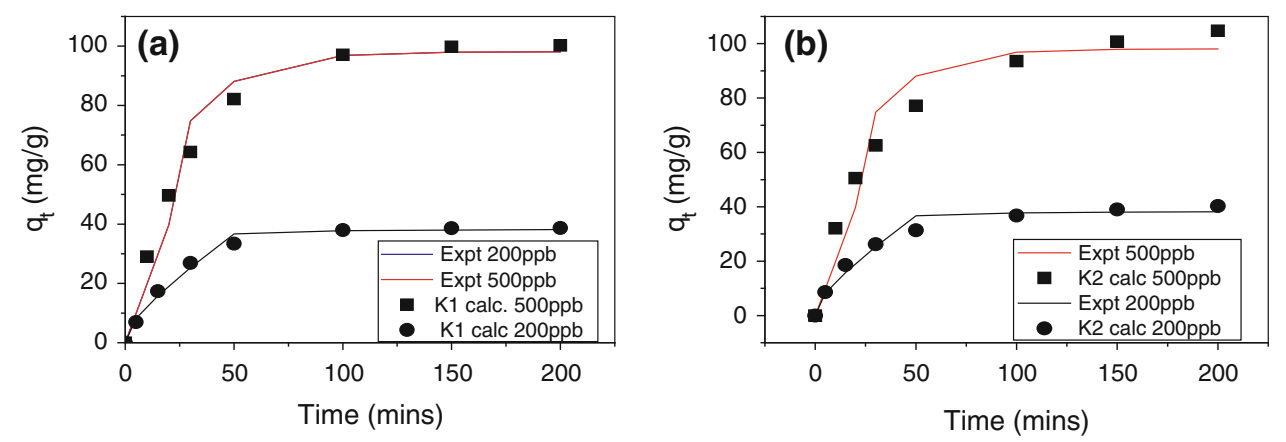

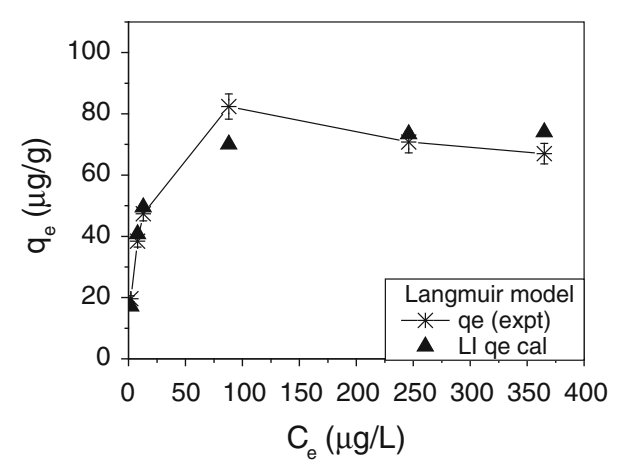

Fig. 6 Showing the Langmuir isotherm

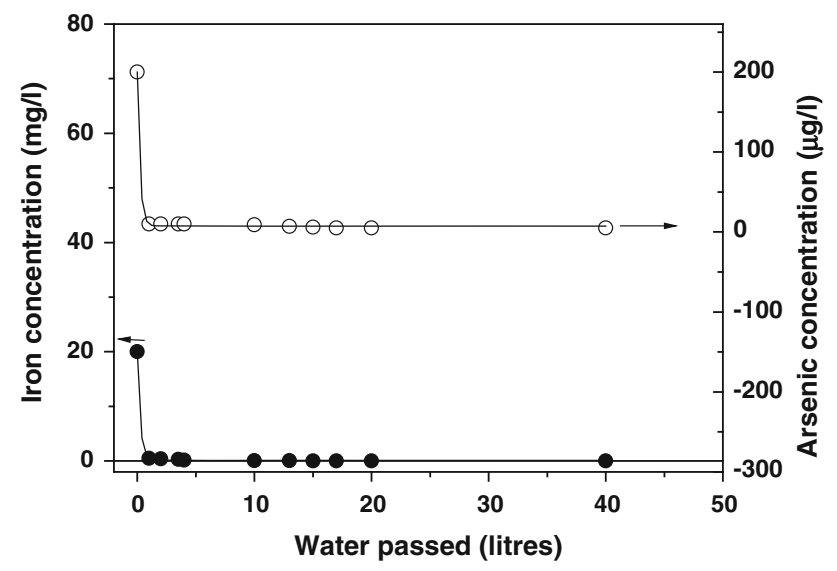

Fig. 7 Iron and arsenic removal with increasing contaminant water through the column of sorption $\left(\mathrm{min}^{-1}\right) ; k_{2}$ is the second-order rate constant of sorption $(\mathrm{g} / \mathrm{mg} / \mathrm{min})$ and $t$ is the time ( $\mathrm{min})$.

Figure 5 illustrates the kinetics of sorption at two arsenic (III) initial concentrations of 200 and $500 \mu \mathrm{g} / \mathrm{l}$. The kinetics data fitted well to pseudo-first order than the pseudo-second order model based on correlation coefficient $R^{2}$ and lower values of root-mean square error. The calculated values of $q_{\mathrm{e}}$ for the pseudo-first order kinetics were found to be $0.03870 \mathrm{mg} / \mathrm{g}$ (for $200 \mu \mathrm{g} / \mathrm{l}$ ) and $0.1003 \mathrm{mg} / \mathrm{g}$ (500 $\mu \mathrm{g} / \mathrm{l})$, respectively, whereas the calculated value of $q_{\mathrm{e}}$ for the pseudo-second order for the arsenic concentration of 200 and $500 \mu \mathrm{g} / \mathrm{l}$ were found to be 0.0444 and $0.1189 \mathrm{mg} / \mathrm{g}$, respectively.

Adsorption isotherms

Langmuir isotherms

Adsorption of arsenic (III) ions from dilute solutions can be represented by Langmuir isotherms (Langmuir 1919). The Langmuir sorption isotherm model is applied for quantitative evaluation of sorption performance which can be written as follows

$q_{\mathrm{e}}=\frac{q_{\mathrm{m}} b C_{\mathrm{e}}}{1+b C_{\mathrm{e}}}$

where $q_{\mathrm{m}}$ is the maximum adsorption capacity of the adsorbent (mg/g), $b$ is the Langmuir constant $(1 / \mathrm{mg}), q_{\mathrm{e}}$ and $C_{\mathrm{e}}$ are the equilibrium adsorption capacity and
Fig. 8 Effect of flow rate on the removal efficiency of (a) arsenic and (b) iron
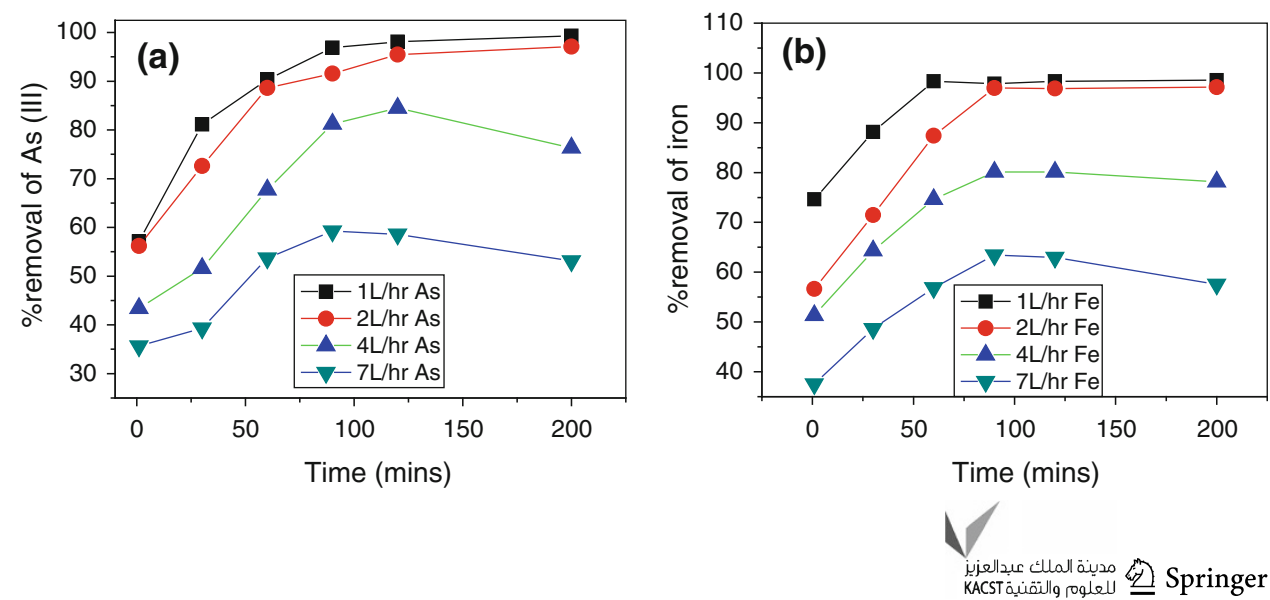
concentration of adsorbate in solution, respectively. The maximum adsorption capacity of the adsorbent and the Langmuir constant calculated non-linearly were found to be $0.075 \mathrm{mg} / \mathrm{g}$ and $150 \mathrm{l} / \mathrm{mg}$, respectively. The plot of $C_{\mathrm{e}}$ versus $q_{\mathrm{e}}$ is given in Fig. 6.

\section{Column studies}

\section{Removal efficiency of iron and arsenic}

A column experiment was conducted to investigate the iron and arsenic (III) removal efficiency with a mixture of iron and arsenic-spiked water. The column (Fig. 1) is effective in removing iron and arsenic (III) to $<0.3 \mathrm{mg} / \mathrm{l}$ and $10 \mu \mathrm{g} / \mathrm{l}$, respectively, from an initial concentration of $20 \mathrm{mg} / \mathrm{l}$ and $200 \mu \mathrm{g} / \mathrm{l}$ when a total of 40 litres of spiked water was passed through the column as seen in Fig. 7.

\section{Effect of flow rate}

Study on the flow rate was conducted at different flow rates of 1, 2, 4 and $7 \mathrm{l} / \mathrm{h}$, respectively. The adsorption of arsenic (III) and iron was found to increase with decreasing flow rate from 7 to 1 1/h, respectively, as shown in Fig. 8. This may be due to the fact that the availability of reaction sites which is able to capture more ions around or inside the cells at a lower flow rate of $1 \mathrm{l} / \mathrm{h}$. Percentage removal of both iron and arsenic (III) was observed to be comparable when the flow rate was set at 1 and $21 / \mathrm{h}$, though the flow rate of $1 \mathrm{l} / \mathrm{h}$ is slightly better. But for practice, it is assumed that $2 \mathrm{l} / \mathrm{h}$ will have an added advantage than $1 \mathrm{l} / \mathrm{h}$ of flow rate based on the quantity of water produced. Further, there was a decrease in the removal capacity when the rate of flow increases from 4 to $7 \mathrm{l} / \mathrm{h}$ on increasing the timing from 120 to $200 \mathrm{~min}$. This may be due to the fact that with increasing flow rate the retention time between the active sites of the adsorbent and the adsorbate becomes less and this trend is further decreased with increasing flow rate (Ghorai and Pant 2005).

\section{EDX analysis and FT-IR study}

The surface elements distribution of iron oxide-coated sand was studied with an EDX analyser. Figure 9 shows the EDX images of uncoated sand (a), iron oxide-coated sand (b), arsenic (III) adsorbed coated sand (c) and coated sand after iron removal (d). Figure $9 \mathrm{~b}$ for iron oxide-coated sand clearly shows the presence of iron, silica and oxygen. Similarly, Fig. 9c of arsenic (III) adsorbed coated sand shows the adsorption of arsenic as it appeared in the EDX spectrum. Again Fig. 9d confirms the presence of iron on coated sand.
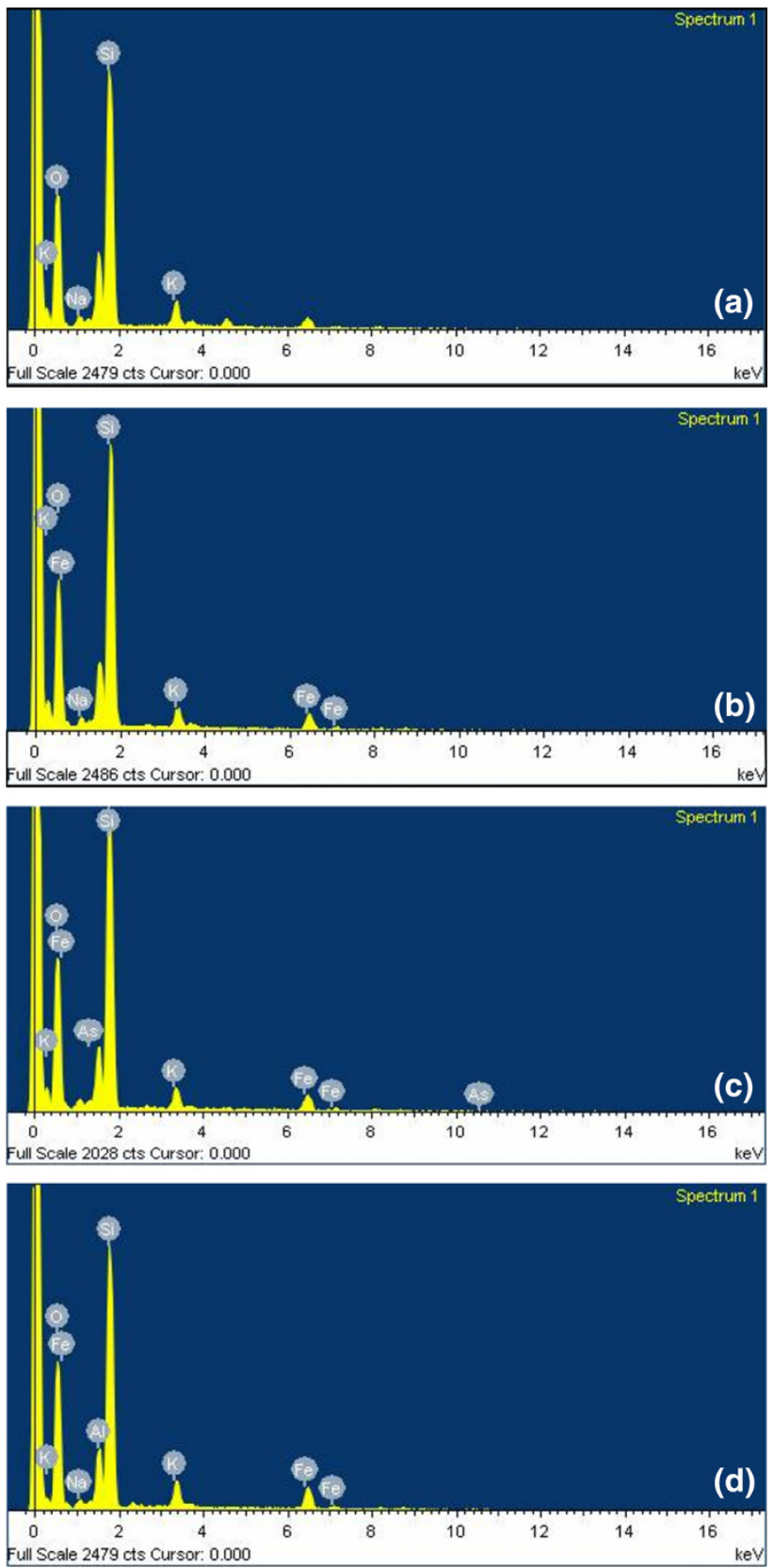

Fig. 9 a EDX spectrum of uncoated sand. b EDX spectrum of iron oxide-coated sand. c EDX spectrum of arsenic adsorbed coated sand. d EDX spectrum of coated sand after iron removal

Figure 10a (i) shows that that peak at $591 \mathrm{~cm}^{-1}$ is due to weak absorption of $\mathrm{Fe}-\mathrm{O}\left(\mathrm{Fe}_{3} \mathrm{O}_{4}\right)$ and a medium band at $529 \mathrm{~cm}^{-1}$ may be due to $\mathrm{Fe}-\mathrm{O}\left(\mathrm{Fe}_{2} \mathrm{O}_{3}\right)$. The band at $643 \mathrm{~cm}^{-1}$ is due to $\mathrm{Si}-\mathrm{O}-\mathrm{Si}$ and that at $795 \mathrm{~cm}^{-1}$ due to $\mathrm{Si}-\mathrm{O}$, while absorption at $618 \mathrm{~cm}^{-1}$ may be due to symmetric stretching of $\mathrm{Fe}-\mathrm{O}$ (Palanivel and Velraj 2007). There is no appreciable difference in the respective peaks in Fig. 10a (ii). Only slight shifting of the peak positions are seen, which clearly shows the presence of iron on iron oxide-coated sand. 

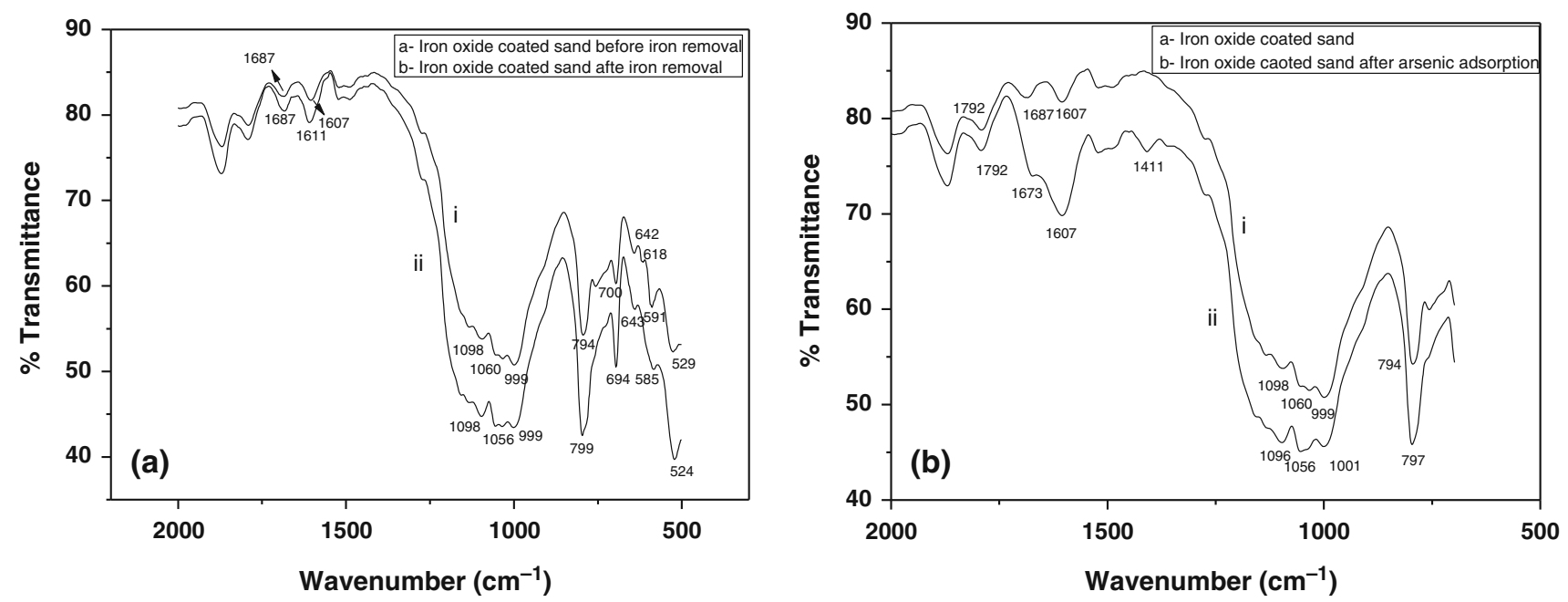

Fig. 10 a FT-IR spectra of iron oxide-coated sand (i) before and (ii) after iron removal. b FT-IR spectra of iron oxide-coated sand (i) before and (ii) after arsenic adsorption

Table 3 Desorption study

\begin{tabular}{lllcl}
\hline $\begin{array}{l}\text { Initial conc. } \\
\text { of } \mathrm{As}(\mathrm{III}) \\
\left(\mu \mathrm{g} \mathrm{L}^{-1}\right)\end{array}$ & $\begin{array}{l}\text { Eluent } \\
\text { used }\end{array}$ & $\begin{array}{l}\text { Conc. of } \\
\text { eluent } \\
(\mathrm{M})\end{array}$ & $\begin{array}{l}\text { Conc. of As(III) } \\
\text { in eluent after } \\
\text { treatment }\left(\mu \mathrm{g} \mathrm{L}^{-1}\right)\end{array}$ & $\begin{array}{l}\text { Regeneracy } \\
\text { of adsorbent } \\
(\%)\end{array}$ \\
\hline 200 & $\mathrm{NaOH}$ & 0.1 & 70 & 35 \\
200 & $\mathrm{NaOH}$ & 0.2 & 90 & 45 \\
200 & $\mathrm{NaOH}$ & 0.5 & 140 & 70 \\
200 & $\mathrm{HCl}$ & 0.1 & 50 & 25 \\
200 & $\mathrm{HCl}$ & 0.2 & 60 & 30 \\
200 & $\mathrm{HCl}$ & 0.5 & 110 & 55 \\
\hline
\end{tabular}

The band at $1,098 \mathrm{~cm}^{-1}$ may be attributed to the formation of hydroxo complexes $(-\mathrm{FeOH},-\mathrm{Fe}-\mathrm{OH}-\mathrm{Fe})$ of metal hydroxides (Holland and Yamaura 2009) [Fig. 10b (i)]. After arsenic adsorption, no significant difference was found in the peak positions except increase in the intensity of peaks and a slight shift of the positions. The peak at $794 \mathrm{~cm}^{-1}$ [Fig. 10b (i)] shifted to $797 \mathrm{~cm}^{-1}$ [Fig. 10b (ii)], which may be due to As-O absorption in the $\mathrm{AsO}_{4}{ }^{3-}$ group (Goldberg and Johnston 2001). The peak at $1,607 \mathrm{~cm}^{-1}$ (due to $\mathrm{Fe}-\mathrm{OH}$ complexes) becomes intense after arsenic adsorption [Fig. 10b (ii)].

\section{Desorption study}

The exhausted iron oxide-coated sand was regenerated with eluents like dilute $\mathrm{HCl}$ and dilute $\mathrm{NaOH}$ (Viswanathan et al. 2009). All the regeneration experiments were carried out at room temperature. Desorption efficiency of iron oxide-coated sand was studied using $0.1,0.2$ and $0.5 \mathrm{M} \mathrm{HCl}$ and $0.1,0.2$ and $0.5 \mathrm{M} \mathrm{NaOH}$ as eluents. From Table 3, it is evident that out of the two eluents, $\mathrm{NaOH}$ had been identified as the best as it had $70 \%$ desorption efficiency, whereas $\mathrm{HCl}$ showed a maximum of $55 \%$ desorption efficiency.

\section{Conclusions}

From the present study it can be concluded that:

(1) Iron oxide-coated sand can be used to remove both iron and arsenic (III) effectively.

(2) Limestone helps more effectively towards removal of iron than arsenic.

(3) The maximum dose of coated sand required for best removal of iron was 5 and $0.2 \mathrm{~g} / 100 \mathrm{ml}$ of limestone. Arsenic (III) removal efficiency increased with increasing dose of coated sand. $97.5 \%$ arsenic removal was obtained at a coated sand dosage of $5 \mathrm{~g} / 100 \mathrm{ml}$ with or without limestone.

(4) $\mathrm{pH}$ plays an important role in the removal capacity of iron oxide-coated sand.

(5) Kinetics data fitted well for pseudo-first order model than pseudo-second order model.

(6) The maximum adsorption capacity $q_{\mathrm{m}}$ of iron oxidecoated sand obtained from Langmuir model was $0.075 \mathrm{mg} / \mathrm{g}$ and $q_{\mathrm{e}}$ from pseudo-first order model was found to be $0.038 \mathrm{mg} / \mathrm{g}$.

(7) Column experiment demonstrated that iron and arsenic (III) were removed effectively from $20 \mathrm{mg} / \mathrm{l}$ iron and $200 \mu \mathrm{g} / \mathrm{l}$ arsenic (III)-spiked water using limestone and coated sand to $<0.3 \mathrm{mg} / \mathrm{l}$ and $10 \mu \mathrm{g} / \mathrm{l}$, respectively.

(8) EDX analysis and FT-IR findings supported the removal of iron and arsenic (III). 
(9) A filtration system containing iron-coated sand and limestone can be used in small-scale or household purposes for effective removal of iron and arsenic (III) from contaminated water.

Open Access This article is distributed under the terms of the Creative Commons Attribution License which permits any use, distribution, and reproduction in any medium, provided the original author(s) and the source are credited.

\section{References}

Banerjee S, Das B, Umlong IM, Devi RR, Kalita H, Saikia LB, Borah K, Raul PK, Singh L (2011) Heavy metal contaminants of underground water in Indo Bangla Border Districts of Tripura, India. Int J ChemTech Res 3:516-522

Benadin V (2011) Effective and affordable novel arsenic removal technology. http://digitalcommons.wku.edu/stu_hon_theses/318

Boddu VM, Abburi K, Talbott JL, Smith ED, Haasch R (2008) Removal of arsenic (III) and arsenic (V) from aqueous medium using chitosan-coated biosorbent. Water Res 42(3):633-642

Chakrabarti D, Singh EJ, Das B, Shah BA, Hossain MA, Nayak B, Ahamed S, Singh NR (2008) Groundwater arsenic contamination in Manipur, one of the seven North-Eastern Hill states of India: a future danger. Environ Geol 56:381-390

Chakraborti D, Sengupta MK, Rahman MM, Ahamed S, Chowdhury UK, Hossain MA, Mukherjee SC, Pati S, Saha KC, Dutta RN, Quamruzzaman Q (2004) Groundwater arsenic contamination and its health effects in the Ganga-Meghna-Brahmaputra plain. J Environ Monit 6:74-83

Chen W, Parette R, Zoau J, Cannon FS, Dempsey BA (2007) Arsenic removal by iron-modified activated carbon. Water Res 41:1851-1858

Garg NK, Hassan Q (2007) Alarming scarcity of water in India. Curr Sci 93:932-941

Ghaly AE, Kamal MA, Core R (2007) Effect of temperature on the performance of limestone/sandstone filters treating landfill leachate. Am J Environ Sci 3(1):11-18

Ghorai S, Pant KK (2005) Equilibrium, kinetics and breakthrough studies for adsorption of fluoride on activated alumina. Sep Purif Technol 42:265-271

Goldberg S (2002) Competitive adsorption of arsenate and arsenite on oxides and clay minerals. Soil Sci Soc Am J 66(2):413-421

Goldberg S, Johnston CT (2001) Mechanisms of arsenic adsorption on amorphous oxides evaluated using macroscopic measurements, vibrational spectroscopy, and surface complexation modelling. J Colloid Interface Sci 234:204-216

Gupta VK, Saini VK, Jain N (2005) Adsorption of As (III) from aqueous solutions by iron oxide-coated sand. J Colloid Interface Sci 288(1):55-60
Holland H, Yamaura M (2009) Synthesis of magnetic nanoparticles by microwave irradiation and characterization. Seventh International Latin-American Conference on Powder Technology (PTECH), Atibaia

Jeon C-S, Baek K, Park J-K, Oh Y-K, Lee S-D (2009) Adsorption characteristics of $\mathrm{As}(\mathrm{V})$ on iron-coated zeolite. J Hazard Mater 163:804-808

Joshi A, Chaudhuri M (1996) Removal of arsenic from ground water by iron oxide-coated sand. J Environ Eng 122(8):769-771

Klaassen CD (2001) Heavy metals and heavy-metal antagonists, section XVI toxicology. In: Hardman JG, Limbird LE (eds) The pharmacological basis of therapeutics. McGraw-Hill Medical Publishing Division, New York, pp 1862-1863

Ladeira ACQ, Ciminelli VST, Duarte HA, Alves MCM, Ramos AY (2001) Mechanism of anion retention from EXAFS and density functional calculations: arsenic (V) adsorbed on gibbsite. Geochim Cosmochim Acta 65:1211-1217

Langmuir I (1919) The constitutional and fundamental properties of solids and liquids. J Am Chem Soc 38:2221-2295

Mackintosh GS, Villiers HA (1998) Treatment of soft, acidic, ferruginous groundwater using limestone bed filtration: a case study. http://www.ewisa.co.za/misc/WISAconf/default1998.htm

Palanivel R, Velraj G (2007) FTIR and FT-Raman spectroscopic studies of fired clay artefacts recently excavated in Tamil Nadu, India. Ind J Pure Appl Phys 45:501-508

Sim SJ, Kang CD, Lee JW, Kim WSJ (2001) Treatment of highly polluted groundwater by novel iron removal process. Environ Sci Health Part A 36(1):25-38

Singh SS, Khanikar D (2009) Remediation of water quality during ground water exploitation and management studies with case studies in North Eastern States, regional workshop on water quality management and its related issues in north eastern states. Central ground water authority and Central ground water board, NE region, Guwahati

Singh AK, Bhagawati S, Das TK, Yubbe D, Rahman B, Nath M, Obing P, Singh WSK, Renthlei CZ, Pachuau L, Thakur R (2008) Assessment of arsenic, fluoride, iron, nitrate and heavy metals in drinking water of North-eastern India. Envis Bull Himal Ecol 16 (1):6-12. http://gbpihedenvis.nic.in/HTML/vol16_1/Vol\% 2016_1.pdf

Twindell LG, Robins RG, Hohn JW (2005) The removal of arsenic from aqueous solution by coprecipitation with iron (III). In: Reddy RG, Ramachandran V (eds) Arsenic metallurgy. TMS (The Minerals, Metals \& Materials Society), Warrendale, pp 3-24

Viswanathan N, Sundaram CS, Meenakshi S (2009) Removal of fluoride from aqueous solution using protonated chitosan beads. J Hazard Mater 161:423-430

Vu KB, Kaminski MD, Nunez L (2003) Review of arsenic removal technologies for contaminated groundwater. http://www.ipd.anl. gov/anlpubs/2003/05/46522.pdf

Wang L, Chen A, Fields K (2000) Arsenic removal from drinking water by ion exchange and activated alumina plants. EPA/600/R00/088. Available online at http://www.nepis.epa.gov/adobe/ PDF/30002F1G.pdf 